\title{
C-Tumours and Polyploidy induced by Some Alkaloids of Opium and Cannabis
}

\author{
A. Kabarity, A. El-Bayoumi and A. Habib \\ Department of Botany and Microbiology, Kuwait University, Kuwait
}

Received December 12, 1978

A large number of chemical substances have been found to change the normal pattern of root development. These changes ranging from complete inhibition of root growth to a change in the rate of growth to abnormal growth pattern. Levan (1939) showed that all growth substances such as Indol-3-acetic acid and others cause an inhibition of root elongation when treating the roots of Allium cepa with low concentration of these chemicals. High concentration on the other hand cause swellings of the roots at certain regions. These swellings are similar to the tumors induced by colchicine (C-tumours, Levan 1938). Since then, large number of chemicals showed to cause such c-tumor phenomenon. Fiskesjö (1969) and Ramel (1969) induced c-tumour after treatment Allium roots with organic mercury compounds. Other chemicals were also effective such as certain gases (Fergusen et al. 1950), quinoline (Sampayo 1950), some fatty acids (Wittmer 1965), herbicides (Sawamura 1965), and Treflan (Kabarity and Nahas 1978).

In the present study an attempt to find out the nature and cause of C-tumour induced by papaverine hydrochloride was made. The ability of some alkaloids of opium and cannabis to induce polyploidy was also investigated to understand the mode of action of these alkaloids upon the cells.

\section{Material and methods}

Bulbs of Allium cepa were allowed to germinate in tap water at $20^{\circ} \mathrm{C}$. After the roots grew $2-4 \mathrm{~cm}$, they were placed in solutions which contained the test substances for the time given in the text. The root tips were then fixed in Carnoy 3:1 for 24 hours. The paraffin method was used for preparing root tips which had produced c-tumours. Two parameters were considered in this investigation, namely, the nucleoplasmic index (NP) and counting the number of cell layers from the centre to the epidermal layer which was carried out in ten different sections taken at random from the meristematic zone and the tumour zone in both treated and untreated roots.

\section{Results}

Induction of c-tumours in Allium cepa root tips using papaverine hydrochloride

a. Nature of c-tumour induced by papaverine hydrochloride.

1. Morphological changes in the roots: Papaverine hydrochloride reduced the rate of root growth, so they appear stunt and thick compared with the untreated 
roots, which appeared long and thin.

Swelling in the roots appeared after 3-5 days of treatment. Two types of enlargements were noticed namely: a) Complete swelling along the majority of the root. b) Complete swelling but with certain more enlargement immediately after the $2 \mathrm{~mm}$ terminal tips (Fig. 1).

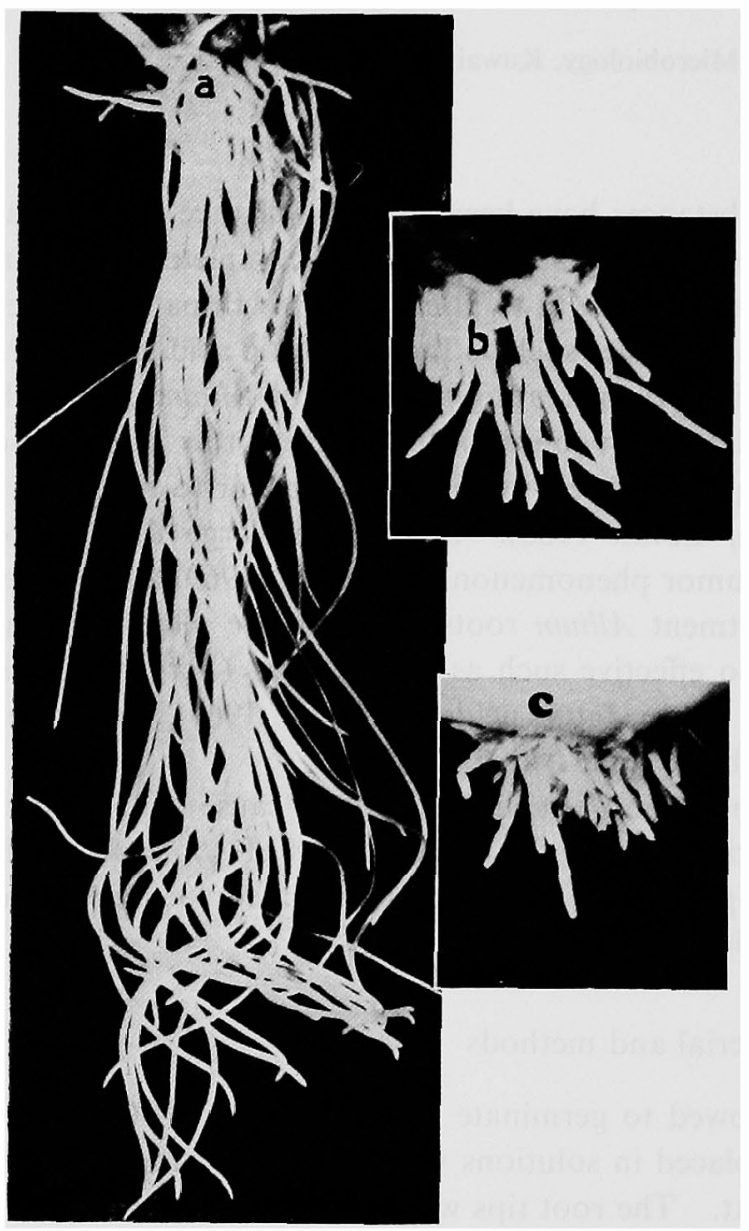

Fig. 1. a, Allium cepa bulbs growing in water for 9 days (control). b and c, Allium cepa bulbs growing in water for 4 days and treated with $0.42 \times 10^{-8} \mathrm{M} / \mathrm{ml}$ papaverine hydrochloride.
2. Histology of the root: Microscopic observations on transverse sections (Fig. 2) of root tips which had been treated showed that the enlargement included both the meristematic and the tumour zones. However, the main swelling area involved the elongation zone of the root. The increase of the radial diameter was found to be due to the abnormal cell enlargement of the cortex and pith areas (Fig. 2), compared with the untreated sections. This enlargement was quite evident from the determination of the surface area of the sections of the different zones. For example, the meristematic zone of the treated roots had a mean area of $0.283 \mathrm{~mm}^{2}$ compared with the untreated roots of the same zone which had an area of $0.094 \mathrm{~mm}^{2}$. This area was greatly increased with more than four folds in the tumour zone, where the value of treated area was $1.130 \mathrm{~mm}^{2}$ compared with the control value of 0.262 $\mathrm{mm}^{2}$ (Table 1).

The increase in surface section area which causes the abnormal tumour swelling of the root was found to be due to cell enlargement of the cortex and pith layers rather than due to increase in cell number. This was proved from the determination of the number of cell layers from centre of the section to the piliferous layer. Table 1 shows that the number of cell rows in the treated roots is more than the untreated ones by almost five rows. Such difference remains the same in both the meristematic and tumour zones. Thus it could be concluded that the abnormal complete swelling along the majority of the root was due to both cell enlargement and to an increase in cell number. Whereas the abnormal tumour swelling was 
found to be mainly due to cell enlargement.

Such cell enlargement of the cortex and pith areas involved only the cell volume whereas the nucleus volume remained constant in cells of the treated and untreated roots and in both zones. This conclusion was evident from the results obtained of the nucleoplasmic index (Table 1).

3. Rate of cell division: The number of cells in interphase and mitotic stages of roots treated with $0.42 \times 10^{-6}$ $\mathrm{M} / \mathrm{ml}$ papaverine hydrochloride for 4 to 120 hours which gave the tumour are shown in Table 2. It is clear that the mitotic index decreased in roots treated for 4 hours then increased to a maximum of 10.17 (compared with the 6.66 control value) in roots treated for 48 hours. Then followed by a linear drop until complete inhibition of cell division in roots treated for 120 hours.

This result indicated that the cell number increased up to 48 hours treatment where it started to drop once again. Such results explain the reason for the partial increased in cell layer number before the ctumour has been developed, while during the development of the tumour no increase in cell number due to the reduction of
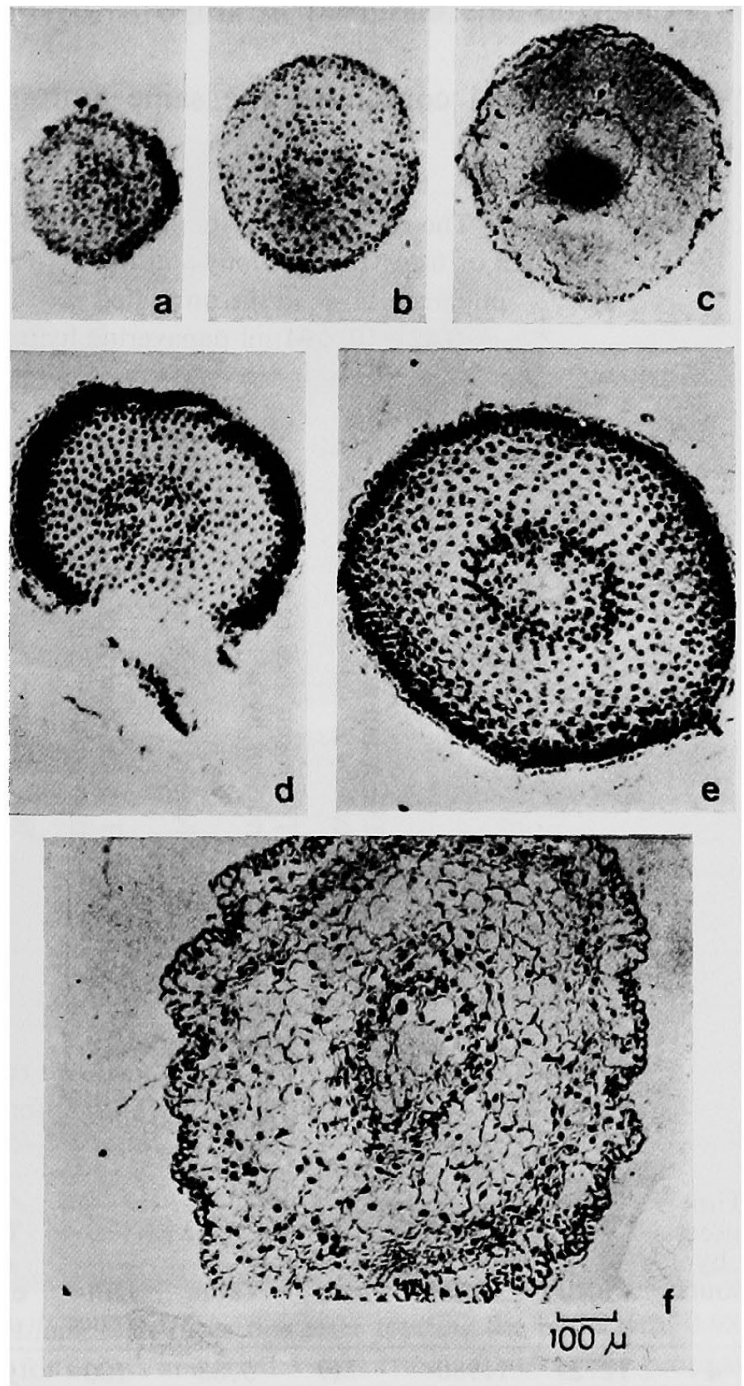

Fig. 2. a-c, T.S. in Allium cepa roots grown in water (control). d-f, T. S. in Allium cepa roots after 5 days treatment with $0.42 \times 10^{-6} \mathrm{M} / \mathrm{ml}$ papaverine hydrochloride. a and $\mathrm{d}$ growing point; $\mathrm{b}$ and e second zone above the growing point; $\mathrm{c}$ and $\mathrm{f}$ tumor zone. MI.

\section{b. Induction of polyploidy after using some alkaloids of opium and cannabis}

In the present work the following chemicals were investigated for the induction of polyploidy in Allium cepa bulbs.

a. Papaverine hydrochloride $\left(0.0,0.8,1.6,3.3,6.6,13.2,19.8\right.$ and $26.4 \times 10^{-6}$ $\mathrm{M} / \mathrm{ml})$.

b. Morphine sulphate $\left(0.0,0.49,0.98,1.97\right.$ and $\left.3.94 \times 10^{-6} \mathrm{M} / \mathrm{ml}\right)$. 
c. Pantopon hydrochloride $(0.0,0.5,1$ and $2 \mathrm{mg} / \mathrm{ml})$.

d. Cannabis crude dissolved in water $(0.0,0.7,3.1,9.3$ and $15.6 \mathrm{mg} / \mathrm{ml})$.

e. Cannabis oils dissolved in ethylene glycol and water $(0.75,1.5,3.0$ and 4.5 $\mathrm{mg} / \mathrm{ml})$.

f. Parallel control containing the same amount of ethylene glycol in water was also tested.

Table 1. The maen area of the nucleus, cell, and their nucleoplasmic index, area of transverse sections and the number of layers from centre to piliferous layer in the untreated root tips of Allium cepa with $0.42 \times 10^{-6} \mathrm{M} / \mathrm{ml}$ papaverine hydrochloride for 5 days

\begin{tabular}{|c|c|c|c|c|c|c|c|c|c|c|}
\hline & \multicolumn{5}{|c|}{ Meristematic zone } & \multicolumn{5}{|c|}{$\begin{array}{l}\text { Tumour zone in the treated roots } \\
\text { and the zone corresponding to it } \\
\text { in the untreated roots }\end{array}$} \\
\hline & 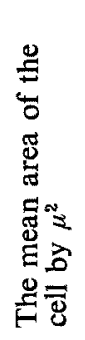 & 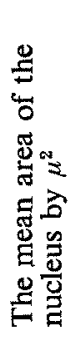 & 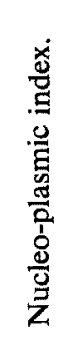 & 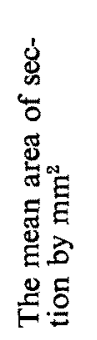 & 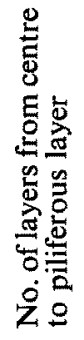 & 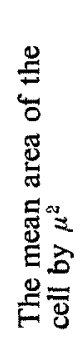 & 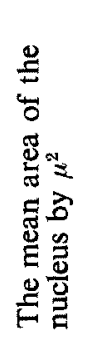 & 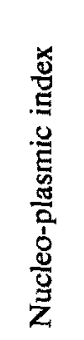 & 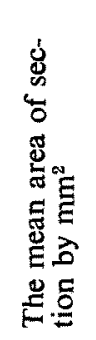 & 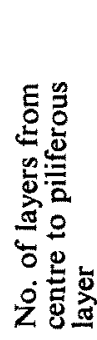 \\
\hline $\begin{array}{l}\text { Untreated root } \\
\text { "Control" }\end{array}$ & 298 & 149 & 1.00 & .094 & 15 & 722 & 134 & 0.23 & 0.262 & 16 \\
\hline Treated root & 573 & 164 & 0.40 & .283 & 20 & 1584 & 134 & 0.09 & 1.130 & 21 \\
\hline
\end{tabular}

Table 2. Mitotic index after treating Allium cepa roots with $0.42 \times 10^{-8} \mathrm{M} / \mathrm{ml}$ papaverine hydrochloride for 4-120 hours

\begin{tabular}{|c|c|c|c|c|c|c|c|c|c|c|}
\hline \multirow{3}{*}{$\begin{array}{l}\text { Time } \\
\text { used } \\
\text { by } \\
\text { hours }\end{array}$} & \multirow{3}{*}{$\begin{array}{l}\text { Total } \\
\text { cells } \\
\text { exam- } \\
\text { ined }\end{array}$} & \multicolumn{4}{|c|}{ Untreated roots } & \multicolumn{5}{|c|}{ Treated Roots } \\
\hline & & \multirow{2}{*}{$\begin{array}{l}\text { No. of } \\
\text { interph- } \\
\text { ase }\end{array}$} & \multirow{2}{*}{$\begin{array}{l}\text { Total } \\
\text { mit- } \\
\text { osis }\end{array}$} & \multicolumn{2}{|c|}{ M.I. } & \multirow{2}{*}{$\begin{array}{l}\text { Total } \\
\text { cells } \\
\text { exam- } \\
\text { ined }\end{array}$} & \multirow{2}{*}{$\begin{array}{l}\text { No. of } \\
\text { inter- } \\
\text { phase }\end{array}$} & \multirow{2}{*}{$\begin{array}{l}\text { Total } \\
\text { mit- } \\
\text { osis }\end{array}$} & \multicolumn{2}{|c|}{ M.I. } \\
\hline & & & & Value & $\begin{array}{l}\text { Diff- } \\
\text { erence }\end{array}$ & & & & Value & $\begin{array}{l}\text { Differ- } \\
\text { ence* }\end{array}$ \\
\hline 4 & 12729 & 11980 & 749 & 5.88 & 100 & 9505 & 9151 & 354 & 3.72 & 63.2 \\
\hline 12 & 9977 & 9414 & 563 & 5.64 & 100 & 13046 & 12245 & 101 & 6.14 & 108.9 \\
\hline 24 & 11156 & 10322 & 634 & 5.68 & 100 & 11516 & 10822 & 694 & 3.03 & 106.2 \\
\hline 48 & 11181 & 10435 & 745 & 6.66 & 100 & 12316 & 11063 & 1253 & 10.17 & 152.8 \\
\hline 72 & 14111 & 12960 & 1131 & 8.02 & 100 & 15955 & 15385 & 570 & 3.57 & 44.5 \\
\hline 96 & 8000 & 7508 & 492 & 6.15 & 100 & 8000 & 7807 & 193 & 2.41 & 39.3 \\
\hline 120 & 8000 & 7537 & 463 & 5.97 & 100 & 8000 & 8000 & 000 & 0.00 & 0.00 \\
\hline
\end{tabular}

* As expresed by a ratio of the M.I., value of the nutreated roots/value of the treated roots.

The test chemicals applied in the present study showed an effect on the rate of growth of the shoot system of Allium cepa. A linear decrease in growth with the increase of concentration applied was noticed.

Cytological investigations indicated that the control roots possessed normal mitotic phases, where all the cells in the meristematic region had the diploid chromo- 
some number. The roots taken from the treated bulbs on the other hand showed certain degree of polyploidy. The polyploidy level varied from root to the other. The majority, however, were having cells containing the tetraploid (Figs. 3, 4).

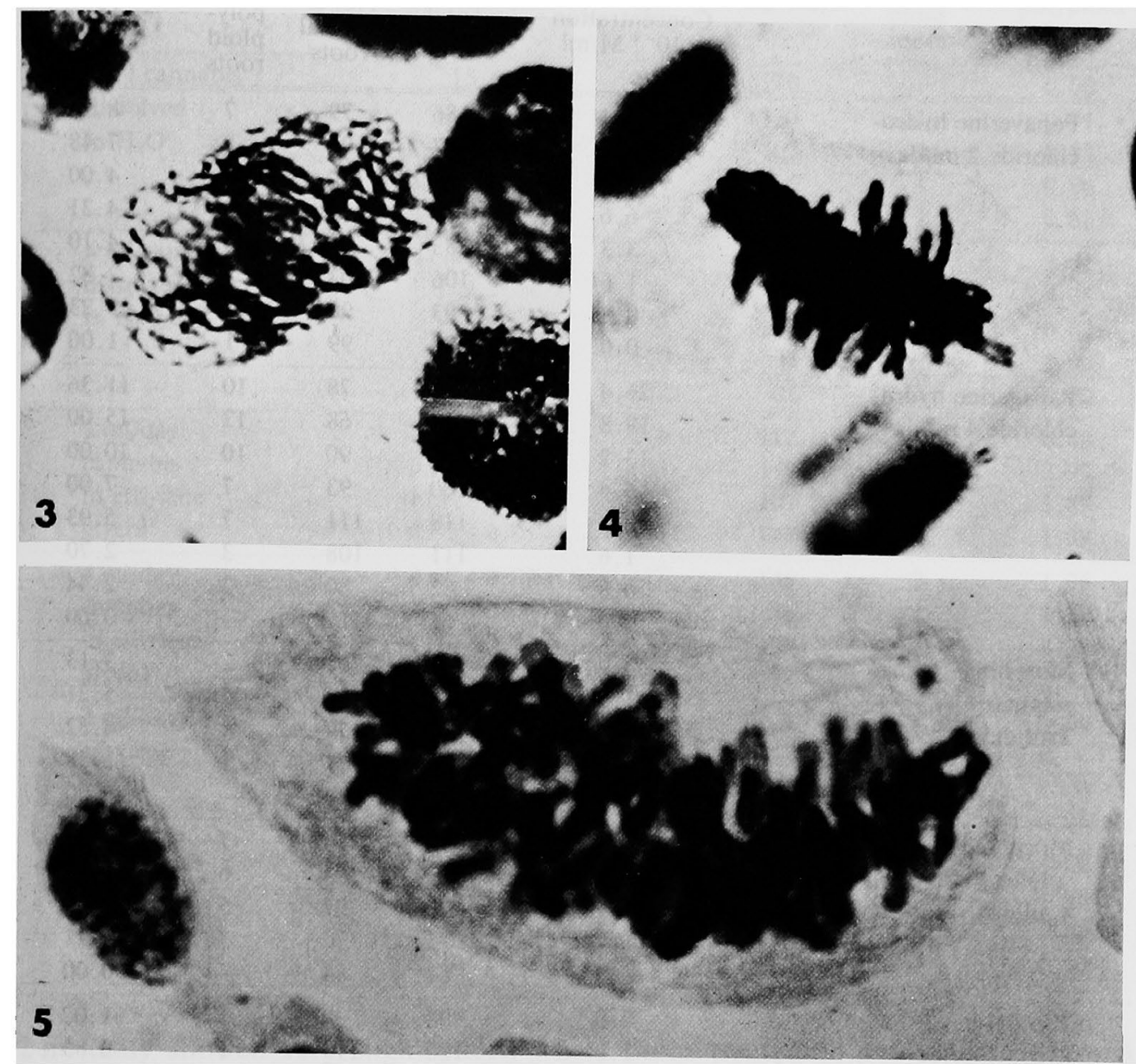

Figs. 3-5. Polyploid mitotic stages in Allium cepa roots tips after treating the bulbs with $0.98 \times$ $10^{-5} \mathrm{M} / \mathrm{ml}$ morphine sulphate (4 ml/day) for 6 days and fixed 6 days later. 3, tetraploid prophase. 4 , tetraploid metaphase. 5, octaploid metaphase.

Nevertheless, higher level of polyploidy which may reach up to octoploid number was also detected among other normal and tetraploid cells (Fig. 5). The polyploidy involved either the whole of the meristematic cells or represented a mixoploid in the same root.

The majority of cells undergone normal mitotic stages except few showed some types of abnormalities particularly those possessing high chromosome number.

Generally, in all chemical substances applied, the treatment with $4 \mathrm{ml}$ daily was found effective than those treated with $2 \mathrm{ml}$ daily in inducing roots with polyploid cells. The frequency of roots having polyploid chromosome number varied according to the type and concentration of chemical applied throughout the two sets of bulbs (Table 3). 
Table 3. Frequency of normal and polyploid roots after treating Allium cepa bulbs with papaverine hydrochloride, morphine sulphate and pantopon hydrochloride for 6 days and fixed 6 days later

\begin{tabular}{|c|c|c|c|c|c|}
\hline & $\begin{array}{l}\text { Concentration } \\
\times 10^{-6} \mathrm{M} / \mathrm{ml}\end{array}$ & $\begin{array}{c}\text { Total } \\
\text { no. }\end{array}$ & $\begin{array}{l}\text { No. of } \\
\text { normal } \\
\text { roots }\end{array}$ & $\begin{array}{l}\text { No. of } \\
\text { poly- } \\
\text { ploid } \\
\text { roots }\end{array}$ & $\begin{array}{l}\% \text { of } \\
\text { polyploid } \\
\text { roots }\end{array}$ \\
\hline Papaverine hydro- & 26.4 & 86 & 79 & 7 & 8.14 \\
\hline \multirow[t]{7}{*}{ chloride $2 \mathrm{ml} / \mathrm{day}$} & 19.8 & 107 & 94 & 8 & 7.48 \\
\hline & 13.2 & 125 & 120 & 5 & 4.00 \\
\hline & 6.6 & 116 & 111 & 5 & 4.31 \\
\hline & 3.3 & 83 & 79 & 4 & 4.10 \\
\hline & 1.6 & 106 & 103 & 3 & 2.82 \\
\hline & 0.8 & 93 & 90 & 3 & 3.23 \\
\hline & 0.0 & 100 & 99 & 1 & 1.00 \\
\hline \multirow{8}{*}{$\begin{array}{l}\text { Papaverine hydro- } \\
\text { chloride } 4 \mathrm{ml} / \text { day }\end{array}$} & 26.4 & 88 & 78 & 10 & 11.36 \\
\hline & 19.8 & 80 & 68 & 12 & 15.00 \\
\hline & 13.2 & 100 & 90 & 10 & 10.00 \\
\hline & 6.6 & 100 & 93 & 7 & 7.00 \\
\hline & 3.3 & 118 & 111 & 7 & 5.93 \\
\hline & 1.6 & 111 & 108 & 3 & 2.70 \\
\hline & 0.8 & 82 & 80 & 2 & 2.44 \\
\hline & 0.0 & 67 & 67 & - & 0.00 \\
\hline \multirow{5}{*}{$\begin{array}{l}\text { Morphine } \\
\text { sulphate } \\
2 \mathrm{ml} / \text { day }\end{array}$} & 3.94 & 64 & 62 & 2 & 3.13 \\
\hline & 1.97 & 96 & 91 & 5 & 5.21 \\
\hline & 0.98 & 83 & 79 & 4 & 4.82 \\
\hline & 0.49 & 78 & 77 & 1 & 1.28 \\
\hline & 0.00 & 81 & 81 & - & 0.00 \\
\hline \multirow{5}{*}{$\begin{array}{l}\text { Morphine } \\
\text { sulphate } \\
4 \mathrm{ml} / \mathrm{day}\end{array}$} & 3.94 & 63 & 56 & 7 & 11.11 \\
\hline & 1.97 & 94 & 88 & 6 & 6.38 \\
\hline & 0.98 & 102 & 97 & 5 & 4.90 \\
\hline & 0.49 & 73 & 70 & 3 & 4.11 \\
\hline & 0.00 & 84 & 84 & - & 0.00 \\
\hline \multirow{4}{*}{$\begin{array}{l}\text { Pantopon } \\
\text { hydrochloride } \\
2 \mathrm{ml} / \mathrm{day}\end{array}$} & 2.0 & 98 & 97 & 1 & 1.02 \\
\hline & 1.0 & 120 & 119 & 1 & 0.83 \\
\hline & 0.5 & 122 & 114 & 8 & 6.56 \\
\hline & 0.0 & 79 & 79 & - & 0.00 \\
\hline \multirow{4}{*}{$\begin{array}{l}\text { Pantopon } \\
\text { hydrochloride } \\
4 \mathrm{ml} / \mathrm{day}\end{array}$} & 2.0 & 96 & 93 & 3 & 3.13 \\
\hline & 1.0 & 112 & 109 & 3 & 2.68 \\
\hline & 0.5 & 110 & 104 & 6 & 5.45 \\
\hline & 0.0 & 76 & 76 & - & 0.00 \\
\hline
\end{tabular}

Papaverine hydrochloride and morphine sulphate showed roughly a linear increase in the percentage of induced polyploid roots as the concentration of the chemical increased (Table 3). For example, a maximum of $15 \%$ of polyploid roots were induced in roots of the bulbs treated with $4 \mathrm{ml}$ daily of a concentration of $19.8 \times 10^{-6} \mathrm{M} / \mathrm{ml}$ papaverine hydrochloride.

The effect of cannabis dissolved in water on the rate of polyploid induction varied according to the concentration of chemical applied. In bulbs treated with 
Table 4. Frequency of normal and polyploid roots after treating Allium cepa bulbs with cannabis for 6 days and fixed 6 days later

\begin{tabular}{|c|c|c|c|c|c|}
\hline & $\begin{array}{l}\text { Concentration } \\
\mathrm{mg} / \mathrm{ml} \text { water }\end{array}$ & $\begin{array}{l}\text { Total } \\
\text { no. }\end{array}$ & $\begin{array}{l}\text { No. of } \\
\text { normal } \\
\text { roots }\end{array}$ & $\begin{array}{l}\text { No. of } \\
\text { poly- } \\
\text { ploid } \\
\text { roots }\end{array}$ & $\begin{array}{l}\text { \% of } \\
\text { polyploid } \\
\text { roots }\end{array}$ \\
\hline $2 \mathrm{ml}$ cannabis & 15.6 & 130 & 130 & - & 0.00 \\
\hline dissolved & 9.3 & 140 & 139 & 1 & 0.71 \\
\hline \multirow[t]{3}{*}{ in $\mathrm{H}_{2} \mathrm{O}$} & 3.1 & 103 & 102 & 1 & 0.97 \\
\hline & 0.7 & 116 & 115 & 1 & 0.86 \\
\hline & 0.0 & 160 & 159 & 1 & 0.62 \\
\hline $4 \mathrm{ml}$ cannabis & 15.6 & 105 & 101 & 4 & 3.81 \\
\hline dissolved & 9.3 & 96 & 87 & 9 & 9.38 \\
\hline \multirow[t]{3}{*}{ in $\mathrm{H}_{2} \mathrm{O}$} & 3.1 & 120 & 107 & 13 & 10.83 \\
\hline & 0.7 & 100 & 97 & 3 & 3.00 \\
\hline & 0.0 & 82 & 82 & - & 0.00 \\
\hline $2 \mathrm{ml} /$ day & $4.50+0.06$ & 113 & 112 & 1 & 0.88 \\
\hline cannabis & $3.00+0.04$ & 134 & 130 & 4 & 2.99 \\
\hline in ethylene & $1.50+0.02$ & 111 & 109 & 2 & 1.89 \\
\hline glycol & $0.75+0.01$ & 144 & 142 & 2 & 1.39 \\
\hline $4 \mathrm{ml} / \mathrm{day}$ & $4.50+0.06$ & 147 & 145 & 2 & 1.36 \\
\hline cannabis & $3.00+0.04$ & 77 & 76 & 1 & 1.30 \\
\hline in ethylene & $1.50+0.02$ & 137 & 131 & 6 & 4.38 \\
\hline glycol & $0.75+0.01$ & 142 & 138 & 4 & 2.82 \\
\hline $2 \mathrm{ml} / \mathrm{day}$ & 0.06 & 125 & 125 & - & 0.00 \\
\hline ethylene & 0.04 & 112 & 112 & - & 0.00 \\
\hline \multirow[t]{2}{*}{ glycol } & 0.02 & 100 & 100 & - & 0.00 \\
\hline & 0.01 & 116 & 115 & 1 & 0.86 \\
\hline $4 \mathrm{ml} / \mathrm{day}$ & 0.06 & 106 & 106 & - & 0.00 \\
\hline ethylene & 0.04 & 113 & 113 & - & 0.00 \\
\hline \multirow{2}{*}{ glycol } & 0.02 & 104 & 104 & - & 0.00 \\
\hline & 0.01 & 110 & 110 & - & 0.00 \\
\hline
\end{tabular}

$2 \mathrm{ml}$ daily showed very slight effect, where bulbs treated with $4 \mathrm{ml}$ daily showed higher effect.

Cannabis dissolved in ethylene glycol, on the other hand showed slight fluctuation of polyploid root frequencies but generally with very low frequency. While the parallel control of ethylene glycol showed no effect on the root tips of Allium cepa (Table 4).

\section{Discussion}

Tumours were formed in root tips of Allium cepa due to the treatment with papaverine hydrochloride. It was found in this investigation that the main reason for these swellings in the roots are due to the abnormal enlargement of the region between the meristematic area and the differentiated cells of a root. Normally, cells elongate linearly to the axis of the root. They seem to show a polarity in this respect. When papaverine hydrochloride is present, an enlargement of the cell 
takes place in all directions. That is, an isodiametric expansion occurs, rather than a polarize elongation. Cells of the cortex and pith become inflated. This leads to a swelling at the particular place along the root. Sections of treated and untreated roots show five or six layers of cells, where the change occurs, and reveals particularly the difference in the shape of individual cells. These comparative studies confirm the opinion that direction of the growth is altered when papaverine hydrochloride is present. This action was also found after the treatment with colchicine (Eigsti and Dustin 1955). Growth promoting substances, as naphthalene acetic acid and indolebutyric acid induce tumours (Berger and Witkus 1949, Levan 1942). Rasch (1964) stated that there was no evidence of non-chromosomal DNA in tumour cells. DNA synthesis extends over $50-60 \%$ of the interphase period in both normal and tumorous bean tissues.

Not all compounds that create tumours arrest mitosis. In fact, certain phytohormones that do not stop mitosis may induce root tip enlargements. The idea of an autonomy of c-mitosis and c-tumours gains support from these general observations with several chemicals (Levan and Östergren 1943).

Generally, favourable conditions for growth increase the promotion of a tumour through a specific treatment (Levan and Steinegger 1947). The range in concentration is fairly broad, but there are limits marked by minimum and maximum concentrations. The formation of tumours within certain limits is proportional to concentration. Finally, the thresholds for c-mitosis and c-tumours are close to each other with some indication that the threshold for the latter process is lower than that for c-mitosis (Levan and Östergren 1943).

As soon as the independence of c-mitosis and c-tumour was suspected, a specific experiment was designed to test autonomy (Levan 1942). Root primordia of Allium fistulosum were subjected to intense X-ray treatment. Consequently, the mitotic capacity of meristematic cells were destroyed. Following X-irradiation, bulbs were placed over colchicine, and typical c-tumours formed with no evidence for several days of the presence of c-mitosis in these roots. Therefore enlargement occurs without a simultaneous division of cells. Polyploidy following a c-mitosis is not necessary for tumour formation (Levan 1942). Swelling at the hypocotyl where seedlings were soaked in colchicine gave the first evidence that tumours were in no way related to c-mitosis or induced polyploidy. Although cells in the hypocotyl are not meristematic, they are capable of elongating or expanding. Colchicine causes an isodiametric expansion of cells much the same as among cortical cells in roots (Hawkes 1942).

The tumour formation is proportional to concentration within certain limits (Geremling 1939). Different species show different degrees of response to the same concentration. Another factor is the specific moment when seedlings are placed in colchicine (Weyland 1948). If the seedling has not yet elongated, there is swelling throughout the entire hypocotyl. But the seedling, that has already elongated to about $23 \mathrm{~mm}$ before the beginning of treatment, it shows practically no swelling at the hypocotyl (Rees 1950). All these points fall in line with the proposition that tumour formation is basically a growth response to chemical used.

Stems of Tradescantia cut from the plant and placed in colchicine show ex- 
treme swelling at the node where leaves are attached (Gowan et al. 1953). The nodal enlargements are in every respect comparable to root and hypocotyl tumours. A petiolar swelling also may occur if leaves expanding are placed in colchicine.

The growth response observed for roots and stems raised the quesion of a possible hormone action. However, the standard tests for measuring phytohormone potency gave negative results (Havas 1949). No responses were obtained from colchicine applied to the Avana, Helianthus and Pisum tests (Rees 1950). Chemicals which induce c-tumours are not a phytohormone, but the basic relation between growth responses shown by tumours and the reactions noted for phytohormones in causing cell enlargement is not yet understood.

The present study indicated that cannabis as well as the different pure synthetic alkaloids had the ability to induce polyploidy. The percentage of roots showing the polyploid nature varied according to the type and concentration of chemical. It was found that papaverine hydrochloride is the most effective substance in this respect. Where cannabis oils showed the least effect. The results obtained were from roots fixed after six days from the end of ehcmical treatment. This period of time was capable to change the direct effect of the chemical, that means the majority of cells showing any abnormality can be restored to its normal condition. For this reason, the frequency of abnormal mitotic stages were very low. However, once the cell is under the influence of the chemical, inhibition or disturbance of spindle fibers occurs. Such cells when recovered, a restituted cell with the tetraploid chromosome number is produced. This is followed by a normal mitosis with the double number of chromosomes moving to the opposite poles. In others this process is repeated and octoploid cells are formed. These were the case when root tips of Allium cepa were treated with cannabis, pantopon and some of their derivatives as mentioned before.

\section{Summary}

Papaverine hydrochloride induces c-tumours in root tips of Allium cepa. Two types of enlargements were noticed, complete swelling along the majority of the root and complete swelling with a certain enlargement immediately after the $2 \mathrm{~mm}$ terminal tips. The histological examination of these zones revealed that these swelling were due to cell enlargement both in meristematic and in tumour zones. This conclusion was evidenced from the result obtained of the nucleoplasmic index.

Papaverine hydrochloride and morphine sulphate showed roughly polyploid roots as the concentration of the chemical increased. The effect of cannabis dissolved in water on the rate of polyploid induction varied according to the concentration applied.

\section{Literature}

Berger, C., and Witkus, E. 1943. A cytological study of c-mitosis in the polysomatic plant Spinacia oleracea with comparative observation on Allium cepa. Torrey. Bot. Club. Bull. 70: 457-467.

Eigsti, O. J. and Dustin, P. 1955. Colchicine in Agriculture, Medicine, Biology and Chemistry. 
Iowa State College Press, Ames, Iowa, U.S.A.

Fergusen, J., S. W. Hawkins and D. Doxey 1950. C-Mitotic action of some simple gases. Nature (London) 165(4208): 1021-1022.

Fiskesjö, G. 1969. Some results from Allium tests with organic mercury halogenides. Hereditas $62: 314-322$.

Geremling, G. 1939. Troubles morphologiques détermines par la colchicine chez végétaux. Assoc. France Avanc. Sci., 63rd. session Liege, p. 595-607.

Gowan, Me., Joan, L. and Charles, J. B. 1953. A cytological study of colchicine induced nodal "Tumors" in Tradescantia. Cancer Res. 13: (9): 646-650.

Havas, L. 1949. Hormone-mimetic and growth effects of colchicine in plants. Exp. Cell Res. Suppl. 1: 597-601.

Hawkes, J. 1942. Some effects of the drug colchicine on cell division. Jour. Genet. 44: 11-22.

Kabarity, A. and Nahas, A. 1978. Induction of polyploidy and C-tumors after treating Allium cepa root tips with the herbicide Treflan. Biologia Plantarum (Praha), in Press.

Levan, A. 1938. Effect of colchicine on root mitosis in Allimum. Hereditas 24: 471-486.

- 1939. Cytological phenomena connected with the root swelling caused by growth substances. Hereditas (Lund) 25: 87-96.

- 1939. Cytological phenomena connected with the root swelling caused by growth substances.

- 1942. The macroscopic colchicine effect-a hormonic action. Hereditas 28: 2444-45.

- and Östergren., G. 1943. The mechanism of c-mitotic action. Observations on the naphthalene series. Hereditas 29: 381-443.

- and Steinegger, E. 1947. The resistance of Colchicum and Bulbocodium to the c-mitotic action of colchicine. Hereditas 33: 552-66.

Ramel, C. 1969. Genetic effects of organic mercury compounds I. Cytological investigations on Allium roots. Hereditas $61: 208-230$.

Rasch, E. M. 1964. DNA synthesis in plant tumor cells. Exp. Cell Res. 36(3): 445-486.

Rees, G. 1950. Beiträge zur Wirkung des Colchicins bei der Samenbehandlung. Planta. 38: 324-376.

Sampayo, T. M. 1950. The action of quinoline on root tip mitosis in Allium cepa L. Genetia Iberica 2(1): 53-74.

Sawamura, S. 1965. Cytological studies on the effect of herbicides on plant cells in vivo II. Nonhormonic herbicides. Cytologia 30: 325-348.

Weyland, H. 1948. The action of chemicals on plants and its significance in medicine. Krebsforsch. 56: $148-164$.

Wittmer, G. 1965. Cytological activation of some fatty acids components. The extracted old and young seeds of Nicotianae. Att. Ass. Genet. Ital. 7:250-256. 